Cuad. Invest. Filol., 43 (2017), 7-31. http://doi.org/10.18172/cif.2959

\title{
EUPHEMISM AND DYSPHEMISM DURING THE WAR OF THE SPANISH SUCCESSION (1710-1713): GEORGE RIDPATH
}

\author{
Raquel Sánchez Ruiz \\ University of Castilla-La Mancha \\ Raquel.SanchezRuiz@uclm.es
}

\begin{abstract}
Euphemism and dysphemism are common within political communication as the former is a linguistic make-up leading to deception and distortion of reality (Rodríguez González 1991: 90) whereas the latter highlights the most pejorative traits of the taboo with an offensive aim (Crespo-Fernández 2015: 2). Considering this, I have analysed euphemism and dysphemism in George Ridpath's political writings during the War of the Spanish Succession (1710-1713), in a corpus comprising two journals (The Observator and The Flying Post), and examined how this author used language to shape and manipulate Great Britain's public opinion during the Stuart period. To this end, I have followed Taboada and Grieve's (2004) approach of Appraisal Theory (Martin and White 2005) as well as Politeness Theory (Brown and Levinson 1987), Face Theory (Goffman 1967), Charteris-Black's Critical Metaphor Analysis (2005: 45) and Conceptual Metaphor Theory (Gibbs 2011). The findings show that Ridpath used x-phemistic language to positively self-present the ingroup and negatively other-present the outgroup.

KEYWORDS: euphemism, dysphemism, George Ridpath, political writings, War of the Spanish Succession.
\end{abstract}

\section{EUFEMISMO Y DISFEMISMO DURANTE LA GUERRA DE SUCESIÓN ESPAÑOLA (1710-1713): GEORGE RIDPATH}

Resumen: El eufemismo y el disfemismo aparecen frecuentemente en la comunicación política, pues el primero es un maquillaje lingüístico para el engaño y la distorsión de la realidad (Rodríguez González 1991: 90) mientras que el segundo destaca los atributos más peyorativos del tabú para ofender (Crespo-Fernández 2015: 2). Partiendo de ahí he analizado ambos recursos en los escritos políticos de George Ridpath durante la Guerra de Sucesión Española (1710-1713), en un corpus que abarca dos periódicos (The Observator $y$ The Flying Post), con el fin de esclarecer cómo manipula y moldea la opinión pública británica mediante el lenguaje durante el periodo Estuardo. Para ello he seguido el enfoque de la Teoría de la Valoración (Martin y White 2005) de Taboada y Grieve (2004), así como la Teoría de la Cortesía (Brown y Levinson 1987), la Teoría de la Imagen (Goffman 1967), el Análisis Crítico de la Metáfora de Charteris-Black (2005: 45) y la Teoría de la Metáfora Conceptual (Gibbs 2011). Los resultados demuestran que Ridpath empleó el lenguaje eufemístico y disfemístico para representar positivamente al propio grupo y negativamente al oponente.

Palabras clave: eufemismo, disfemismo, George Ridpath, escritos políticos, Guerra de Sucesión Española. 


\section{Introduction}

The means of communication constitute not only a source of information and transmission of ideology, but also a forum of reproduction of ideology and social legitimation. Within these means, the press has a special capacity to establish particular values and reference models for the public opinion as well as to reproduce dominant ideologies and social conceptions; hence, its value in the political field as a weapon of ideological persuasion and manipulation which politicians use according to their interests and postures.

Political communication is a breeding ground for euphemism and dysphemism. On the one hand, euphemistic language is employed in political speeches as a linguistic make-up leading to deception and distortion of reality, also known as doublespeak (Lutz 1987: 20-21) or doublethink (Rodríguez González 1991: 51, 90) and official euphemism (Abrantes 2005: 88). On the other hand, dysphemism "rarely appears in ordinary language" as it means "speaking offensively" (Allan and Burridge 2006: 29); that is, "the process whereby the most pejorative traits of the taboo are highlighted with an offensive aim to the addressee or to the concept itself” (Crespo-Fernández 2015: 2). Both devices are essential within politics since they contribute to positively self-presenting the ingroup and negatively other-presenting the outgroup through polarisation (van Dijk 1999: 95) and legitimation/delegitimation (Chilton 2004); two phenomena that will be explained below.

Considering the above, I have analysed George Ridpath's use of euphemism and dysphemism in his political writings during the War of the Spanish Succession (1710-1713) to observe how this author employed language as a weapon to shape and manipulate Great Britain's public opinion during the Stuart period. The corpus of investigation comprises two journals (The Observator and The Flying Post: or, the Post-Master), four years (1710-1712 and 1711-1713 respectively) and 291 numbers (126 and 165 respectively).

In order to analyse the corpus data, I have relied on the frames of Taboada and Grieve's (2004) approach of Appraisal Theory (Martin and White 2005), Politeness Theory (Brown and Levinson 1987), Face Theory (Goffman 1967), as well as Charteris-Black’s Critical Metaphor Analysis (2005: 45) and Conceptual Metaphor Theory (Gibbs 2011), which will be presented in the following section.

The choice for Ridpath is not casual, since he has not been paid enough attention (McLeod and McLeod 1979: 194) although he contributed to the great political debates of the reign of Queen Anne from 1702 to 1714 (Crespo-Fernández 
and López Campillo 2011: 47). The selection of this period is not random either, because, as Crespo-Fernández and López Campillo (2011: 44) state, during the late Stuart period the press was of vital importance to spread ideas and information, "and both Whigs and Tories and the Ministry itself recognised the press as an organ of political influence (cf. López Campillo 2009)” (Sánchez Ruiz 2015: 110). Furthermore, while there is a growing literature addressing persuasion in Great Britain's political writings during the late Stuart period (Barker 2000; Black 2001) or the War of the Spanish Succession (Müllenbrock 1997; Losa Serrano and López Campillo 2007; López Campillo 2009, 2010), little scholarship has focused on George Ridpath (Crespo-Fernández and López Campillo 2011; Sánchez Ruiz and López Cirugeda 2015; Sánchez Ruiz 2015). From a more contemporary perspective, it is worthy of note that this period is still relevant nowadays, since the Scottish and Catalan independence issues and some problems between Spain and Gibraltar have their origin in the War of the Spanish Succession.

\section{Theoretical framework and methodology}

As mentioned in the Introduction, in this study, I have followed Taboada and Grieve's (2004) approach of Appraisal Theory (Martin and White 2005), Politeness Theory (Brown and Levinson 1987), Face Theory (Goffman 1967), Charteris-Black's Critical Metaphor Analysis (2005: 45) and Conceptual Metaphor Theory. Moreover, both the phenomena of polarisation (van Dijk 1999: 95) and legitimation and delegitimation (Chilton 2004) take part in the analysis. The concepts of euphemism, dysphemism, $\mathrm{x}$-phemism, quasi-euphemism, quasidysphemism, metaphor and metonymy are also discussed here.

Euphemism is "the process whereby the taboo is stripped of its most explicit or obscene overtones” (Crespo-Fernández 2015: 2). And this phenomenon and, by extension dysphemism, is tied to politeness through the concept of face; indeed, $\mathrm{x}$-phemism can be defined in relation to the notion of face and face affront. Because euphemism is aimed at preserving the speaker's or writer's public image or face in communicative interactions and, therefore, maintaining the social harmony in interpersonal relations by avoiding the potential face-affronts that some taboo words or expressions may present (Crespo-Fernández 2015: xii, 45-46).

Politeness Theory (Brown and Levinson 1987) and Face Theory (Goffman 1967) are, thus, interrelated. The former derives from the notion of face proposed by Goffman (1967) and states that one's more or less polite behaviour depends on two factors: the desire of humans that their actions are not impeded by others 
(negative face) and the desire of humans that their wants or self-image are appreciated and approved of (positive face) (Brown and Levinson 1987: 13). Facework is likewise essential in the analysis of communicative interactions since, depending on the image the speaker wants to show, a particular kind of devices is employed. For example, if the speaker feels that their statements are too direct or uncomfortable and may be a potential threat to their image or the receiver's, politeness strategies, euphemistic language and hedges will be employed to soften the speech and so as not to damage their social and public image.

Moreover, as Allan and Burridge (2006: 29, 32-33) claim, euphemism is related to Face Theory insofar as this device is "used as an alternative to a dispreferred expression" in order to "avoid possible loss of face by the speaker, and also the hearer or some third party"; because "social interaction is generally oriented towards maintaining (saving) face”. However, McGlone and Batcherlor (2003: 206) have proven that the use of euphemistic units is more oriented towards protecting the positive image of the speaker than preventing the receiver from feeling uncomfortable. As Crespo-Fernández (2014: 8) argues, euphemism is closely linked to Politeness Theory and Face Theory since " $[w]$ hether owing to pressures from the political parties they represent, or on account of the need to appear sensitive and considerate, the fact remains that verbal politeness plays an important role in the politician's strategy to win people's favour". In fact, euphemism can be used for positive self-presentation (van Dijk 1997: 32-33), including the glorification or justification of political actions (Rodríguez González 1991: 94).

Euphemism goes beyond simple lexical substitution, "towards a cognitive dimension", since pragmatic assumptions (a particular context and given situation) are needed to understand "the real sense of its intentions and its function as a communicative value” (Casas Gómez 2009: 725). Furthermore, euphemism is generally figurative, since it is "structured conceptually in many cases, and thus can be fruitfully studied along cognitive lines” (Crespo-Fernández 2015: 47). Indeed, "metaphor stands out as one of the most prolific one [semantic devices] in x-phemism formation", because many " $x$-phemistic units are the result of semantic change and extension” (Crespo-Fernández 2015: 48).

In view of the above, "politicians resort to euphemism as a 'safe' way to deal with unpleasant subjects and criticize their opponents without giving a negative impression to their audiences" or to "deal with certain embarrassing topics without being politically incorrect or breaking a social convention” (Crespo-Fernández 2014: 5, 6). As pointed out in the Introduction, this dark side to euphemism, known as doublespeak, abounds in the political field since it is a linguistic 
make-up leading to deception and the distortion of reality for the speaker's benefit (Rodríguez González 1991: 90) and may be considered an extreme case of euphemism which ultimately implies the inversion of words with a pernicious intention (Crespo-Fernández 2014: 6).

Dysphemism, on the contrary, "is a word of phrase with connotations that are offensive either about the denotatum and/or to people addressed or overhearing the utterance" (Allan and Burridge 2006: 32). So it provides a way to speak about the unspeakable, the inappropriate or the taboo with the aim of offending or "violating the proscription imposed by society or by ourselves" (Crespo-Fernández 2015: 2). This device, along with hyperbolic language, is usually linked to negative other-presentation (van Dijk 1999: 95) to portray the opposition party. Moreover, dysphemism carries evaluative meaning as it "involves negative evaluation of behaviours through emotionally loaded and offensive language" (Crespo-Fernández 2015: 6). This phenomenon can also be defined in relation to face-affronts, as dysphemism is the offensive use of language leading to some kind of face-affront; that is, "an overt damage to the hearer's face or that of some third party involved in the communicative act”, following Allan and Burridge's placement of x-phemistic processes (Crespo-Fernández 2015: 45-46).

Nevertheless, the limits between euphemism and dysphemism are fuzzy sometimes (Chamizo Domínguez 2004: 45); in fact, euphemism can become dysphemism and vice versa (Kröll 1984: 12). This is what Allan and Burridge (2006) call $x$-phemism due to the versatility of particular lexical units to be considered mitigating or offensive in their context. Yet the complexity of euphemism goes beyond. A statement can be euphemistic from a locutionary perspective, but have a dysphemistic illocutionary intention or vice versa. "These conflicting emotions and antagonistic feelings facilitate the existence of dysphemistic euphemisms and euphemistic dysphemisms" (Casas Gómez 2012: 43). However, I will adopt Crespo-Fernández's terms (2015: 46): quasi-euphemism and quasi-dysphemism. The former occurs when the language unit is used positively regardless of its dysphemistic locution. Quasi-euphemism is included in what Burgen (1996: 30-31) defines as joking relationship, that is, breaking the taboo in interpersonal or informal relationships. Crespo-Fernández (2015: 47) classifies quasi-euphemism as preferred, non face-threatening expressions with the following functions: cohesive or "displaying in-group solidarity"; complimentary or praising; dirty or "sexually stimulating the partner"; and ludic or "defusing the seriousness of taboo subjects". Contrary to quasi-euphemism, quasi-dysphemism is intentionally offensive or derogatory in spite of its "socially acceptable disguise” (Crespo-Fernández 2015: 46) and so "provides a 'safe ground' for the 
speaker's [real] offensive intention” through concealment (Crespo-Fernández 2014: 16). Dysphemism and quasi-dysphemism are an effective psychological persuasion strategy within politics, since they serve to attack the political opponent and, thus, persuade the citizen against a particular politician, political situation or faction (Crespo-Fernández 2013).

So as to classify euphemistic and dysphemistic language, I have employed Taboada and Grieve's (2004: 159-161) appraisal method, categorising texts according to their subjective content or sentiment and based on Martin's Appraisal (2000) and Martin and White's Appraisal Theory (2005) and attitude or attitudinal positioning. Attitude is a system of meanings composed of "three semantic regions covering what is traditionally referred to as emotion, ethics and aesthetics”, that is, affect, judgement and appreciation (Martin and White 2005: 42-43). These authors define affect as "positive and negative feelings", judgement as "attitudes towards behaviour", and appreciation as "evaluations of semiotic and natural phenomena, according to the ways in which they are valued or not in a given field”. For their part, Taboada and Grieve's approach (2004) employs the positive and negative semantic orientation of words to analyse and classify language examples and text structure. Therefore, context and pragmatic aspects are considered in the classification of ambiguous lexical units. Positive and negative orientations play a role in the categorisation as they help determine if an example is a case of euphemism, dysphemism, quasi-euphemism or quasi-dysphemism by evaluating the author's opinions and attitude, as well as his political beliefs and the context of the journals. When applying this methodology, I took two steps: first, I divided lexical units into positive and negative regarding their orientation; and second, I classified them into appreciation or a comment on a thing, judgement or a comment on a person, and affect or a comment on one's self.

X-phemism is also related to the phenomena of polarisation (van Dijk 1999: 95) and legitimation/delegitimation (Chilton 2004). The former are mental representations which occur when groups create an ideological image of themselves (ingroup) and others (outgroup) in a way where us are presented positively (positive self-presentation or legitimation in Chilton's terms) and them negatively (negative other-presentation or delegitimation). This paper intends to reveal the roles $\mathrm{x}$-phemism plays in the construction of an alternative reality by which ideological persuasion occurs. To this end, I will relate x-phemism and polarisation and legitimation/delegitimation to demonstrate if euphemism, as a key element of political correctness, constitutes a powerful tool for a hidden attack to the political opponent, and if it occurs more frequently than dysphemism or frontal attacks. 
It must be borne in mind that analysing language in use implies considering human behaviour when communicating, including diverse factors like context or interlocutors' characteristics. This is especially relevant in x-phemism, as it is a context-bound phenomenon and, as such, difficult to categorise.

Finally, metaphor is a productive and revealing $\mathrm{x}$-phemistic device in this paper, so Charteris-Black's Critical Metaphor Analysis (2005: 45) and Conceptual Metaphor Theory (Gibbs 2011) are also employed. On the one hand, the former approach aims at identifying, interpreting and explaining the purported intentions and ideologies of language through figurative language (metaphor and metonymy). On the other hand, Conceptual Metaphor Theory (CMT) or Contemporary Theory of Metaphor (CTM) -first proposed by Lakoff and Johnson (1980) and later complemented by Lakoff and Turner (1989) and Lakoff (1993), among others- does not define metaphor as a linguistic aspect, but an essential part of human thought and thus a matter of cognition; and so 'conceptual metaphors' are 'metaphors of thought' (Gibbs 2011: 529-530). Under this theory, metaphor can be defined as "a 'conceptual mapping' (a set of correspondences) from a source domain (traditional vehicle) to a target domain (traditional tenor)" (Ruiz de Mendoza Ibáñez and Pérez Hernández 2011: 161). Likewise, following Kövecses and Radden (1998: 39), Ruiz de Mendoza Ibáñez and Galera-Masegosa (2011: 5) define [conceptual] metonymy as "a cognitive process in which one conceptual entity, the vehicle, provides mental access to another conceptual entity, the target, within the same conceptual domain”. At the same time, metonymy can be categorised in two types: target-in-source, that is, when the whole domain (the matrix domain) stands for one of its subdomains; and source-in-target, when a subdomain stands for its matrix domain (Ruiz de Mendoza Ibáñez, 2000; Ruiz de Mendoza Ibáñez and Galera-Masegosa 2011: 5). Moreover, the same way metaphors can combine with other metaphors (metaphoric chains) or metonymy with another metonymy, a metaphor can combine with a metonymy creating a conceptual complex known as metaphtonymy (Ruiz de Mendoza Ibáñez and Galera-Masegosa 2011: 1).

\section{The context, the author and the journals}

First, I will briefly deal with the historical and political context where the analysed speeches were written. Then I will present the author, George Ridpath. A description of both journals comparing them to other newspapers and journals of the time will bring this section to an end. 
Anne Stuart's reign (1702-1714) was a turning point for the political history of Great Britain, since both national and international issues regarding the monarchy, the Church and foreign policy were at stake; therefore, party activity was heightened (Crespo-Fernández and López Campillo 2011: 45). This was reinforced by the emergence of the public opinion, favoured by the expiry of the Licensing Act in 1695, which ceased state censorship and political control of the press and contributed to increasing political propaganda, and by the proliferation of clubs where people discussed and spread ideas.

In this context, the English press offered an image of harmony, prosperity, increasing economic welfare and social stability in the reign (López Campillo 2010: 44), with the exception of the last years of the decade when shortage and social discomfort ruled due to the hostilities of the nation with France (Trevelyan 1965: 309). The Queen usually sided with the Tories, who dominated the first administrations of her reign, and mistrusted the Whigs. However, between 1705 and 1708, the Whigs influenced the Queen to cease some Tory ministers, the party who she always trusted (López Campillo 2010: 79). By 1709, the nation claimed the end of the war led by the financial crisis and resource shortages as well as the Allies' victories. In October 1710, the Tories won the general elections since they promised to end the war, while the Whigs held the opposite view (Albareda Salvadó 2010: 22); and, after the Treaty of Utrecht was passed by the Parliament in 1713, the Tories won the elections again (Hattendorf 1987: 2). This shows that the Peace Campaign (1710-1713) was mainly supported by the Tories and propaganda was essential for both parties in order to shape public opinion and persuade the readers. It is worthy of note that Spain was the key in the campaign since, while the Tories claimed the Peace without Spain, the Whigs supported the opposite, No peace without Spain (Losa Serrano and López Campillo 2007: 176).

Turning now to George Ridpath (1660?-1726) and his role in the abovementioned context, he was, as already pointed out in the Introduction, a renowned, polemical Whig and Scottish journalist in the late Stuart period. As Sánchez Ruiz (2015: 112-113) notes, he actively participated in the burning of a representation of the pope and was "accused of threatening to burn the provost's house", since he was openly anti-Catholic and Presbyterian. Apart from five weeks in prison for these crimes, he was also found guilty for two libels in The Observator although he was charged with three of them. During the Stuart period, electors shifted sides, especially those committed to the Tories, who only supported the Whigs when the succession seemed to be threatened (Speck 1970: 114); therefore, Ridpath was crucial to Great Britain's public opinion as the press was thought to persuade 
swing voters. In 1707, Ridpath succeeded John Tutchin in editing The Observator. He also conducted the Whig journal The Flying Post: or, the Post-Master (henceforth The Flying Post) and contributed to another journal, The Medley, in 1712 (Wilson 1830: 253, 283). In 1714, Daniel Defoe -one of Ridpath's rivals along with Abel Roper- started working in The Flying Post. This led Ridpath's relationship with the journal to an end (Lee 1869: 230) and so Ridpath began to call it The Sham Flying Post. Finally, as The Daily Post of 7 February 1716 published, Ridpath died on 5 February, the same day as Abel Roper.

Before the linguistic analysis, I move on to describe the journals comprising the corpus. On the one hand, The Observator was a political periodical founded in 1702 by John Tutchin and was published twice a week. It aimed at denouncing fraud and abuse in the government of London (Auchter 2001: 253-255). However, when Ridpath was in charge of the journal, it was devoted to informing about Parliament resolutions and to indicting the government's pacifist faction of their Jacobite and Frenchfied trends (López Campillo 2010: 155). Its peculiar dialogued structure by the Observer -also called Master- and Roger, voicing his own and his peers' opinions respectively, stands out. In fact, this is particularly interesting since there are relatively few studies analysing persuasion in dialogued texts when persuasive discourse has a potential for a dialogic quality, as "the explicit confrontation of different perspectives [...] promoted by the dialogic form displays the process of influencing the persuadee's views and codes of interpretation in all its complexity" (Boden 2004: 43). During the Peace Campaign, The Observator was key since it was the only Whig journal to form an opinion and was crucial in the peace-war debate (López Campillo 2010: 155). Moreover, it was considered the best representing the opposition to the government (Swift 1711) and the most relevant strictly political Whig organ (Müllenbrock 1997).

On the other hand, The Flying Post: or, the Post-Master, originally The Flying Post from Paris and Amsterdam, was founded in 1695 and was published three times a week. Ridpath edited it from 1697 onwards although, in 1713, because of his conflict with the law, Stephen Whatley played this role at times. Despite not having a dialogued structure, in the corpus of research, this journal addresses some questions to The Observator; and thus, both journals interplayed. This journal was decisive for the Whigs, mainly in the last years of the Stuart Period, when Ridpath defended the Hanoverian cause and attacked the Tory peace (Holmes 1987: 31). Finally, it must be borne in mind that both journals were important in their time (Dunton 1818: 428). 


\section{Analysis and discussion}

\subsection{Euphemism}

As I have followed Taboada and Grieve's (2004: 159-161) approach to attitude within Martin and White's Appraisal Theory (2005), I will start with judgement (moral opinions) or expressions referred to a person, and then I will comment on appreciation (aesthetic opinions) or expressions referred to objects or concepts in each year. No cases of affect (moral opinions) or expressions referred to oneself -author or journal- have been found. This has a direct influence on Ridpath's persuasive and manipulative intentions as well as on the journal's aim, which will be commented in the final remarks. Analysing judgement and appreciation will allow me to draw specific conclusions about those referents and to observe if the frequency or absence of some of them influence the author's persuasive aims. Before the analysis, the following tables show the number of euphemistic cases excerpted from both journals:

Table 1. Euphemism in The Observator

\begin{tabular}{|c|c|c|c|c|c|c|c|}
\hline \multirow{3}{*}{ Category } & \multicolumn{6}{|c|}{ Year } & \multirow{3}{*}{$\mathrm{T}$} \\
\hline & \multicolumn{2}{|c|}{1710 [40 numbers (n)] } & \multicolumn{2}{|c|}{$1711(51 \mathrm{n})$} & \multicolumn{2}{|c|}{$1712(35 n)$} & \\
\hline & Judgement (J) & Appreciation (A) & $J$ & $A$ & $J$ & $A$ & \\
\hline Lexical substitution & 3 & 2 & 8 & 4 & 2 & 1 & 20 \\
\hline Quasi-euphemism & & & 1 & & & & 1 \\
\hline TOTAL (T) & 3 & 2 & 9 & 4 & 2 & 1 & 21 \\
\hline
\end{tabular}

Table 2. Euphemism in The Flying Post

\begin{tabular}{|l|c|l|c|c|c|c|c|}
\hline \multirow{3}{*}{ Category } & \multicolumn{5}{|c|}{ Year } & \multirow{2}{*}{ T } \\
\cline { 2 - 8 } & \multicolumn{2}{|c|}{$1711[13$ numbers (n)] } & $1712(66 \mathrm{n})$ & $1713(86 \mathrm{n})$ & \multirow{2}{*}{} \\
\cline { 2 - 8 } & Judgement $(J)$ & Appreciation (A) & $J$ & $A$ & $J$ & $A$ & \\
\hline Lexical substitution & & & 5 & 37 & 5 & 37 & 84 \\
\hline Quasi-euphemism & & & & & & & \\
\hline TOTAL (T) & & & 5 & 37 & 5 & 37 & 84 \\
\hline
\end{tabular}




\subsubsection{Lexical substitution in The Observator, 1710-1712}

I start with judgement in 1710. Even though the Duke of Marlborough is considered one of the best friends of the King and has a reputation for fighting against the French, he is criticised for having no better friends than a Ministry whom neither God nor man could endure (91'). This statement contributes to proving that the main aim of The Observator is to denounce the faction contrary to the nation according to Ridpath's views. However, criticism does not only focus on nobility or politicians, but also journals and writers, which becomes a cliché in the analysed texts. For example, The Examiner is accused of turning Sacheverell's ${ }^{2}$ sermons into a dictionary of genteel epithets (92); and, for Ridpath, this same journal and its author, Jonathan Swift, seem to have more courage than caution (85).

In 1711, euphemism aims to discredit sources and authors through socially accepted expressions which do not threaten the writer's social image. For instance, Ridpath states Henry [Sacheverell] is the best qualified man in the word for certain employments (34); the fact that the mentioned tasks are omitted stresses more the euphemistic intention as well as calling him by his first name emphasises the ironic sense. The French King, Lewis XIV, is severely criticised as well; he is even affirmed not to be trusted any otherwise than in chains or in a cage (99). In this year another of Ridpath's clichés can be found: treason. Therefore, the author mentions Catiline and Cicero with a cathartic intention, since in ancient Rome the leading plotters were put to death $(7,11)$. These last three words stress the euphemistic locutionary force insofar as they exempt executioners from their responsibility in the performance of their duty. In this vein, "plotters within doors" (7) is a euphemistic expression since it avoids alluding to the opposite faction or political enemies. Example (1) is both metaphorical and euphemistic, as it avoids other terms that evidence the taboo of death or high treason.

1) We never heard of a Whig that broke a penknife against the ribs of a Minister of State (33).

1. Since all the examples are from Ridpath, the repetition of the author and the year will be avoided in every example, as the classification makes them both clear in all cases.

2. Henry Sacheverell (1674-1724) was a member of the High Church of England and a politician. One of his most famous sermons, The Perils of False Brethren, in Church, and State (1709), led him to court. He was judged and suspended for three years; his sentence also included burning two of his sermons in The Royal Exchange. This, together with the high taxes in London, turned him into a martyr, which caused tumults both in London and around the country. This sermon was politically used against the Whigs and the Tories’ political rise (López Campillo 2010: 27, 139). 
Likewise, the use of this precise expression has another double purpose linked to van Dijk's concept of polarisation (1999: 96). On the one hand, it positively self-presents the Whig faction since it denies that they have performed a dishonourable action; and on the other hand, it negatively other-presents the Tories as it implies they have performed the mentioned action.

In 1712, the "art of telling their lies" (15) is euphemistic as it ironically employs the word 'art' as a virtue of those who support the opposite faction instead of reflecting the author's true opinion.

Now I proceed to explain the cases of appreciation. In 1710, another cliché repeats: discrediting sources and authors. Thus, Mr Lesley's -one of Sacheverell's supports- treasonable pamphlet is ironically and euphemistically affirmed to be "the good old cause". In this year another cliché arises: the succession. In example (2) metonymy and euphemism merge; in fact, the first device, by means of 'the hand', turns the expression into a contextual euphemism which strips politicians of their guilt towards the succession, since that based on hereditary rights shall disappear and, thus, supportive monarchs do not have to be mentioned at all.

2) That doctrine which the House of Lords condemned to be burnt by the hand of the hangman (34).

In 1711, euphemism is only employed to avoid the taboo of death. In this sense, Ridpath recommends both the subjects and Britons not to hide any issue from their monarchs if they do not want to hazard their own salvation (42). Another metonymy, where the part (head) stands for the whole (person), is also euphemistic since the Earl of Clarendon is said to have threatened the Queen of England with the loss of her head from Spain (51). Criticism focuses again on the countries Ridpath considers tyrannical, that is, France and the Holy Roman Empire, of which he affirms that they dispose of the lives, liberties and estates of their subjects as they please (9). Finally in this year, the government employs euphemistic units to avoid the word 'death' in its sentences, for example "take someone's life” for the cases of high treason (9).

In 1712, the only case of euphemistic appreciation is related to religion. In it, Ridpath informs that Mr. Hoadly's writings have been condemned "to the flames" so as to avoid a direct reference to hell or evil forces (51). However, the veiled allusion to hell through the FIRE metaphor is present in his message, so Ridpath resorts to the biblical tradition, where this type of images is fruitful. As Charteris-Black (2016) claims, this kind of metaphors is a rich and conceptual resource and persuasive force frequently employed in political speeches to impose authority. 


\subsubsection{Lexical substitution in The Flying Post, 1711-1713}

As can be observed in Table 2, in 1711 there is no euphemism for two reasons: on the one hand, the scarcity of numbers analysed, since only 13 numbers dealt with the War of the Spanish Succession; therefore, not having excerpted any case is neither representative nor determining in the analysis since it might be just a coincidence due to the limitations of the corpus. And on the other hand, the nature of the journal, as it is mainly informative and objective; thus, Ridpath employs neither literary language nor subjective expressions, but short and explanatory sentences, where figures and places specifying events prevail and verbal devices, such as figurative language, euphemistic or dysphemistic expressions, are typically discarded.

In 1712, the first fruitful case of judgement is "prisoners of war" (3239, 3262, 3263, 3265, 3266, 3267 and 3286), which attributes the deprivation of liberty to an action -the war- and, therefore, exempts certain people of it. This same phrase also appears in 1713 (3396). The other cases of judgement refer to sources and authors. For example, Ridpath relates his arch enemy Abel Roper to The Examiner by calling them brothers (3331, 3347 and 3353). The term 'brother', ironically employed, avoids the taboo of being socially impolite and, thus, saves Ridpath's and his journal's public face by preserving his self-image. In example (3), by focusing on himself ("gives me most offence") and not mentioning the opponent, the author avoids a direct face-affront again.

3) This part of the last paragraph is which gives me most offence (3410).

Now I proceed to explain the cases of appreciation, which are all about war in 1712. The "art of war" (3234 and 3300) avoids the taboo of death by equating this act with a socially accepted ability and, thus, dignifying the action of war.

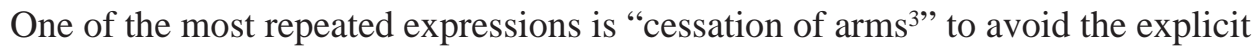
term of 'war'; the same happens with "suspension of arms" (3247, 3259, 3265, 3271, 3307 and 3310). This is a case of doublespeak, as it aims to distort reality and offer a partial view of the concept according to the writer's interests. However, there are also antithetic examples: for instance, "putting an end to the war" (3230 and 3316) avoids the word 'peace' with the intention of highlighting the importance of such an achievement in times of war; contrariwise, the social value

3. It is repeated 29 times: 3230, 3235, 3236, 3238, 3239, 3240, 3241, 3243, 3243b, 3247, 3248, 3356, 3258, 3259, 3260, 3261, 3264, 3265, 3267, 3273, 3276, 3278, 3284, 3286, 3293, 3297, 3304, 3310 and 3313. 
of participating in war is acknowledged by means of "marks of honour" (3266 and 3307), which again dignifies the action and referent through euphemism.

In 1713, another euphemistic omission of the word peace linked to the enemy is found (3325), which demonstrates that silence can function as an effective device to mitigate death and related matters (Crespo-Fernández 2015: 72, 207). The expressions "cessation of arms"," "suspension of arms" (3327 and 3328) and "marks of honour" (3398) are also frequent in this year. However, the meaning of the marks changes depending on who they are referred to; thus, Ridpath affirms that the French were received in Geneva with great "marks of pity" (3401). The case of "be in possession ${ }^{5}$ " is euphemistic in this context of war, since it avoids mentioning the colonisation or deprivation of liberty of the beaten place. Likewise, the key points of the conflict are called "places of arms" (3331) and the attacks, "visits with fire or sword" (3329) so as to avoid the word "war", which is usually mitigated with adverbs and adjectives with their root in "human" (3328) when it appears. Finally, the true criticism of the Catholic religion, which is typically bond to calumny, arbitrariness, slavery and tyranny and equated with atheism, is covered by a "mask of apostolic zeal" (3388).

\subsubsection{Quasi-euphemism}

As already commented, since the main aim of quasi-euphemism is to break the taboo within informal relationships, no cases were found in either journals. Moreover, as journals are part of the written press, and so comply with politeness rules, euphemism and irony as well as quasi-dysphemism are frequently employed. Nevertheless, in 1711 there is a case in The Observator which might be considered self-criticism, but not affect according to Taboada and Grieve (2004: 161) as it is not self-judgement but a hypothesis. In it, Ridpath affirms they would be the most stupid and arrogant in the nation if they did not take measures regarding war (7). In this case, the locutionary force is dysphemistic concerning its form; however, the intention is not dysphemistic since it is not intended to offend or damage the referent's image.

4. This expression appears in the following numbers: 3325, 3326, 3327, 3329b, 3331, 3335, 3338, 3343, 3346, 3347, 3360, 3396 and 3406.

5. This is applied to Flanders (3398), Luxembourg (3392), some Spanish territories (3382 and 3388), Sicily (3379), Cologne and Trier (3390), Savoy (3392), Catalonia (3399 and 3401), Barcelona (3409) and the government of Mecklemburg-Swerin (3410). 


\subsection{Dysphemism}

Tables 3 and 4 show all the cases of dysphemistic lexical substitution and quasi-dysphemism in both journals:

Table 3. Dysphemism in The Observator

\begin{tabular}{|c|c|c|c|c|c|c|c|}
\hline \multirow{3}{*}{ Category } & \multicolumn{6}{|c|}{ Year } & \multirow{3}{*}{$\mathrm{T}$} \\
\hline & \multicolumn{2}{|c|}{1710 [40 numbers $(\mathrm{n})]$} & \multicolumn{2}{|c|}{$1711(51 \mathrm{n})$} & \multicolumn{2}{|c|}{$1712(35 n)$} & \\
\hline & Judgement (J) & Appreciation (A) & $J$ & $A$ & $J$ & $A$ & \\
\hline Lexical substitution & 6 & & 8 & 2 & 11 & 5 & 32 \\
\hline Quasi-dysphemism & 12 & & 17 & 4 & 9 & 5 & 47 \\
\hline TOTAL (T) & 18 & 0 & 25 & 6 & 20 & 10 & 79 \\
\hline
\end{tabular}

Table 4. Euphemism in The Flying Post

\begin{tabular}{|l|c|l|c|c|c|c|c|}
\hline \multirow{3}{*}{ Category } & \multicolumn{5}{|c|}{ Year } & \multirow{2}{*}{ T } \\
\cline { 2 - 7 } & \multicolumn{2}{|c|}{$1711[13$ numbers (n)] } & $1712(66 \mathrm{n})$ & $1713(86 \mathrm{n})$ & \multirow{2}{*}{} \\
\cline { 2 - 8 } & Judgement $(J)$ & Appreciation (A) & $J$ & $A$ & $J$ & $A$ & \\
\hline Lexical substitution & & & 8 & 1 & 5 & 1 & 15 \\
\hline Quasi-dysphemism & & & 4 & 2 & 12 & 2 & 20 \\
\hline TOTAL (T) & & & 12 & 3 & 17 & 3 & 35 \\
\hline
\end{tabular}

\subsubsection{Lexical substitution in The Observator, 1710-1712}

In 1710, all the dysphemistic examples are judgement. The most repeated expressions are "great tyrant" (24 and 67) and "French tyrant" (14) referred to Lewis XIV. As commented before, the Queen's views on political parties change. However, as Ridpath was always a Whig, the most negative adjective applies to the Tories. Then, in this year, Roger tells the Observer that some Whigs say that the latter is a rank Tory, and most of the Tories say that he is an incurable Whig (62). Concerning religion, Ridpath describes the High Church and Papists as an execration in the history of Great Britain (14); and Jacobites and Papists as the greatest fools in the kingdom (81).

In 1711, dysphemism has two main aims: on the one hand, to highlight the French King's worst flaw, that is, being a tyrant (13, 66 and 71). And on the other hand, to criticise The Examiner, Abel Roper and his friends for having prostituted 
their pens to their malicious purposes and their consciences and loyalty to the nation to be retailers of falsehood and slander (10, 29, 49 and 92).

In 1712, the French King is criticised again through all sorts of dysphemistic phrases, like "faithless tyrant” (5), "grizzly tyrant” (5), “cock-a-hoop” (14), "the monster of heresy" (21), "the monster of tyranny and perjury" (21), "the French tyrant” (32) and "haughty tyrant" (16). Ridpath has two main aims when using Kövecses’ pejorative conceptual animal metaphor (2010: 201), PEOPLE ARE ANIMALS, and particularly ENEMIES ARE DANGEROUS ANIMALS, at the same time derived from the conceptualisation of VIOLENT HUMAN BEHAVIOUR IS ANIMAL BEHAVIOUR. First, to offend and insult King Lewis XIV. And second, referring to a person as vermin is defining such person as "disgusting, harmful, untrustworthy and dangerous to society” (Goatly 2006: 279); and therefore, King Lewis XIV’s eradication for the safety of the community is "not only justified, but also seen as a social and vital necessity” (Crespo-Fernández 2013: 318).

But not only is the King liken to a beast, but also the faction, especially the clergy, which is considered a "villainous society" (50); in fact, the dissenters are described as the "monsters of ingratitude to the government" (6). Religion is also one of Ridpath's targets as observed in the following example:

4) Only the great whore of Rome protected the little bastard of Cappadocia, as the great bastard of France protects the little brat of St. Germain (20).

In this last year, dysphemism also focuses on defaming the opposition's authors and journals, especially The Examiner, which is called "silly Mohawk" (22). The High Church is defined as lunatics who shall be turned into fools (38).

Regarding appreciations, in 1711, in the vein of the prostitution of some sources, the hatred against the Catholic Rome is evidenced by its comparison to a harlot (31). Another criticised aspect is the treaty of peace, which is considered mock (96).

In 1712, dysphemistic appreciations have the main purpose of discrediting sources. For example, a number of The Plain Dealer is considered “a contradictory piece of nonsense” (60) and the pamphlet No Queen, or no General, "an indigested rhapsody of words” (6). Language also connects political factions; in this case, patriots" “English sounds a great deal better than all the Jacobite gibberish" (20). Furthermore, one of the journal's main aims is to inform about parliamentary resolutions and criticise the Jacobite faction of the government supporting the French. Therefore, Ridpath expounds that the "parliamentary authority is a thing too sacred to be prostituted to the piques of a French”, that is, King Lewis XIV (5). 


\subsubsection{Lexical substitution in The Flying Post, 1711-1713}

Due to the scarcity of numbers analysed in 1711 and the journal's nature, in this year neither euphemistic nor dysphemistic examples were found.

In 1712, all cases of judgement, except two alluding to the wicked tyranny of Papists, refer to the French King, who Ridpath describes as "a tyrant, a great oppressor, the common enemy, and the prosecutor of their brethren" (3260), "faithless tyrant” (3260), "king of slave-onia” (3260), "the brat” (3292) and, simply, "tyrant" (3271 and 3309).

In 1713, dysphemism appears in the discussion between a Whig and a Tory in a coffee house, where the latter calls the former "child of mutiny" (3325). In line of the reputation of certain sources, The Examiner is portrayed as the "monster of baseness and ingratitude" (3324), through a dysphemistic ANIMAL metaphor with the abovementioned purposes. What is more, in the same sentence, Ridpath ironically labels these journals as follows:

5) This is a Post-Boy; this is My Lord, this is our Dr. of Divinity; this is an Abel, this is a Jonathan, a whore, a schoolmaster (3326).

In this same vein, Ridpath remarks that the faction does "all they can to prostitute the honour of their country" (3334). Likewise, in relation to the enmity with France, the author writes the following:

6) Should have a dozen honest men venture to declare their opinion where they ought, they would be called insulters of the prerogative, and a crew of abandoned wretches (3311).

Concerning dysphemistic appreciation, just two cases are found, one per year. In 1712, the procedure of burying the British fallen is condemned, since men of honour are "thrown into a hole like a dog" (3264); thus the ANIMAL metaphor here is a case of derogatory dysphemism. On the contrary, in 1713, politics merges again with religions and nations, as the idolatry of Rome and the tyranny of France, who are scarlet coloured whores, are chastised (3334 and 3357).

\subsubsection{Quasi-dysphemism in The Observator, 1710-1712}

In 1710, a pseudo-mitigation expression concerning Sacheverell, magnifying the force of the insult, appears. By feeling sorry for Sacheverell, Ridpath 
highlights the ignorance of the person who he considers a vile traitor and, by extension, of his supporters. In this sense, the high-flying clergy, "their trumpeters of rebellion" and Sacheverell -also considered "the champion of slavery" (61) and "trumpeter of sedition" (34)- are distrusted. These expressions merge with veiled and ironic criticism with the intention of discrediting sources; therefore, Ridpath affirms that he finds "there's no other instrument that suits his [The Examiner's] genius" (92). In this same number, the author indicates that he formerly "advised Mr. Examiner to make use of a fine pencil, and to lay aside his plastering-brush". In this year, dysphemism also focuses on the French King and the Holy Roman Emperor; in fact, the latter is ironically named "the Grand Senior" (70) and accused of being Frenchfied (70).

In 1711, sources or authors supporting The Examiner or Abel Roper are criticised due to their friendship and comments (51, 83 and 95). In fact, the former is considered to be "so well versed in the art of political lying" and "the father of lies" (37). Ironically, Ridpath calls The Examiner his "old friend" with a clear offensive and mocking intention (100); the same happens with "his brother", Abel Roper, and both are described as two of the bravest fellows that he ever met with (24). In this same vein, Lewis XIV is called "that great man" (13). Scatology is also employed to discredit the topics dealt with in The Examiner as seen in example (7):

7) A man that always kept a row of pots by him with his own excrements, and made them the whole subject of his conversation (49).

Ridpath notes the necessity to cure The Examiner, Sacheverell and "Abel's sons of the church" (30), negatively other-presenting them. Politics and religions merge in 1711 to remark the "Romish idolatry and French tyranny" (99). And the French King is accused of being "the most notorious breaker of faith" (93), and a tyrant and bigot (101).

In 1712, irony blends with euphemism to produce an offensive result (quasidysphemism), especially to damage the image of the French King and of the authors who support him or the Catholic succession. Thus, Ridpath ironically affirms that they should let "the French King enjoy the greatest part of what he has usurped by perjury and violence" (17). He is also considered the "son of perdition" (52); as well as his supporters are "sons of rebellion and avarice" (54). The rivalry between Ridpath and The Examiner -the latter also considered a "tool of the other party" (56)- is also found in this year, as well as between the author and The Examiner's brothers (39) and prompters (20 and 22). In fact, The 
Examiner is also accused of being a liar and along with Abel Roper and Dyer constitutes the "lying triumvirate" (15).

Now I move on to the cases of appreciation in 1711 and 1712. In this first year, "French tricks and bribes" (102) are shown again. These ruses are also linked to the monarchy as King Jacob's advice to his brother-in-law about Spain is said to be actually threats (90).

In 1712, The Examiner is negatively presented when depicted as Frenchfied and, thus, his political and religious beliefs are linked to the French (32). Jonathan Swift, considered the faction's "invincible champion" (31), and his Conduct of the Allies are deprived from credibility as seen in example (8):

8) Instead of napkins they shall have The Conduct of the Allies and particularly his reflections in the Barrier Treaty to wipe their fingers (18).

However, not only authors and sources are criticised, but also the language employed by some individuals or peoples. For instance, French is described as the "language of the beast" (20), metaphor which again associates animal behaviour to human behaviour, and thus, is offensive (Kövecses 2006: 165). France and Catholicism are also bond to slavery and ironically described as "the sweets of Gallic slavery" to emphasise the negative consequences by using an odd positive expression. Finally, the enemies' pamphlets are considered "a mere jingle of words" (6).

\subsubsection{Quasi-dysphemism in The Flying Post, 1711-1713}

In 1712, the French and Spanish Ambassadors in Switzerland are called "favourers of heretics" (3263). In fact, the French are considered a particular "race of men" who act only according to their own interests (3288). Once again sources and authors are castigated, as in the case of The Examiner, described as "being a manifest lie from beginning to end" (3285), and Abel Roper, accused of introducing his party lies in his writings with a very fashionable faculty of his (3259).

In 1713, the Catholic Pope is questioned -especially when Ridpath supports the end of the war and the achievement of the peace- when the author affirms he should be an indulgent father of peace, and not a fomenter of war (3374). The long debates between Whigs and Tories in coffee houses are a source of euphemistic and dysphemistic expressions. For example, a Whig brands a Tory as "Capitan Pistol” (3325). These discussions both about national and international issues 
are precisely a long process during the whole Peace Campaign; thence the Whig expression "our old friends" (3326) to refer to Tories. Ridpath's words reveal the party he supports since it is always the Whig who answers the Tory sagaciously and quasi-dysphemistic expressions typically focus on the latter. However, other sources and people are concerned as well, such as "Frenchfied and Popishly affected writers" (3402), "Frenchfied churchmen” (3363) or Sacheverell. Instead of using his first name, Ridpath calls him Harry (3325), both stressing the offensive intention and evidencing the mocking effect. Abel Roper is referred to as a "Popish and Jacobite tool" (3325) and The Examiner as the "charmer" (3326), whose friends are also discredited precisely due to their friendship (3397).

As far as appreciation is concerned, in 1712 it deals with sources and authors as well as political and religious beliefs. Abel's masters are said to give the nation their opinion "by their politic tool" (3286); the word 'tool' is clearly ironic and, thus, offensive, since it hides a manipulative purpose. On the other hand, the mitigating expression "signs of aversion" (3295) shows Whig's feelings towards Papism and slavery.

In 1713, so as to avoid the taboo of the Catholic hell, two expressions which emphasise the concept with an offensive aim are used; thus, Papism is a "mark of disgrace" alluding to the "monstrous hot place" (3329b). Likewise, sacred services are perverted, since the act of consecrating is "whipping heresy out" (3400), which negatively presents Catholicism and, through the phenomenon of polarisation, positively self-presents Protestantism; Ridpath's ultimate goal during the whole Peace Campaign.

\section{Conclusions}

The present analysis of euphemistic language shows that in The Observator there are more euphemistic lexical substitutions than quasi-euphemism, and in The Flying Post there are no cases of the latter for two reasons. First, because, in the written press, lexical units must be polite and respectful, at least in appearance. And second, because breaking the taboo in informal, interpersonal relationships (the main aim of quasi-euphemism) does not happen here. Moreover, in both journals, euphemism aims at discrediting sources and authors from the opposite faction, especially Abel Roper, Sacheverell and The Examiner. Ridpath carefully selects those expressions that seem more socially acceptable not to threaten his own image or that of the journal. This phenomenon is essential within politically correct language and, thus, is a powerful weapon to covertly attack the 
political opponent instead of frontal attacks through dysphemism. In The Flying Post, euphemism is mainly used to dignify war; therefore, doublespeak, typical in political discourse, is employed to distort reality and provide a partial view of the mentioned concept according to Ridpath's interests in each moment (first in favour of the war and later of the peace).

As euphemism is a permeable phenomenon, it is combined with other resources to obtain certain effects. For example, it usually merges with positive and negative polarisation to attack his opponents (Abel Roper, Daniel Defoe, The Examiner, Jonathan Swift and Sacheverell) as well as to attract the reader's attention and persuade them with his opinions. Dysphemism also blends with polarisation to legitimate his opinions and delegitimate the opponent through coarse and vulgar language, even direct insults. Nevertheless, quasi-dysphemism is frequent since the written press must preserve social relationships; it is in fact used in order to preserve the speaker's or one's image, as that would discredit the journal and delegitimate their arguments. Likewise, in The Observator, quasi-dysphemism merges with ANIMAL metaphors with offensive and mocking purposes, especially in relation to the faction's sources.

It is also worth noting that dysphemism prevails over euphemism, which means that Ridpath's main intention in both journals is basically to offend. In fact, the subjective nature of The Observator justifies the scarcity of euphemism in this journal, as its main aim is to denounce the government and political parties' unfair actions. What is more, dysphemism and quasi-dysphemism abound despite appearing in the written press. On the contrary, as The Flying Post is more objective and has an informative nature, language is usually concise and, thus, euphemism is usually employed to avoid value judgements.

After implementing Taboada and Grieve's approach to attitude (2004: 159161), two conclusions are drawn. First, the fact that the majority of expressions, especially euphemistic, are negative and judgements reinforces Ridpath's offensive intention and demonstrates that these devices are used persuasively to discredit or criticise the opposite faction (the Tories, especially during the election campaigns), rival sources and authors (The Examiner, Abel Roper, The Review, The Mercator and Henry Sacheverell mainly) or international figures from the opposite faction (the French King, the Emperor and the House of Bourbon). And second, the fact that no affect or comment on one's self has been found suggests that none of the journals are self-critical but criticises the enemy. This reinforces Ridpath's persuasion strategy related to van Dijk's polarization (1999: 95); since, through the negative other-presentation of political, religious and national or 
international rivals, he positively self-presents his ingroup, that is, him and his journals and, therefore, his opinions and beliefs.

Finally, this paper has analysed x-phemism to reveal how George Ridpath employed language to shape and manipulate Great Britain's public opinion in the late Stuart period. And the results seem to confirm that politicians are "well aware of the fact that the lexical choices language users make have a tremendous potential for mass persuasion and a profound impact on how social and political phenomena are perceived" (Crespo-Fernández 2013: 328). Thus, language is a powerful persuasion tool at politicians' disposal not only to shape public opinion according to their interests but also against their political opponents.

\section{References}

ABRANTES, A. M. (2005). "Euphemism and Co-operation in Discourse" in Power without Domination, Dialogism and the Empowering Property of Communication. (Ed. E. Grillo). Amsterdam/New York: John Benjamins.

ALBAREDA SALVADÓ, J. (2010). La Guerra de Sucesión de España (17101714). Barcelona: Crítica.

ALLAN, K. and BURRIDGE, K. (2006). Forbidden Words: Taboo and the Censoring of Language. Cambridge: Cambridge University Press.

AUCHTER, D. (2001). Dictionary of Literary and Dramatic Censorship in Tudor and Stuart England. Westport, CT: Greenwood Press.

BARKER, H. (2000). Newspapers, Politics and English Society 1695-1855. Harlow: Longman.

BLACK, J. (2001). The English Press 1621-1861. Gloucestershire: Sutton Publishing.

BODEN, S. (2004). Persuasive Dialogues in Shakespeare's Dramatic Work. Jena: University Friedrich Schiller.

BROWN, P. and LEVINSON, S. C. (1987). Politeness. Some Universals in Language Use. Cambridge: Cambridge University Press.

BURGEN, S. (1996). Your Mother's Tongue. London: Indigo.

CASAS GÓMEZ, M. (2009). "Towards a New Approach to the Linguistic Definition of Euphemism”. Language Sciences 31: 725-739.

CASAS GÓMEZ, M. (2012). "The Expressive Creativity of Euphemism and Dysphemism”. Lexis. Journal in English Lexicology 7: 43-64.

CHAMIZO DOMÍNGUEZ, P. J. (2004). "La función social y cognitiva del eufemismo y del disfemismo”. Panace@ 15: 45-51. 
CHARTERIS-BLACK, J. (2005). Politicians and Rhetoric. The Persuasive Power of Metaphor ( $2^{\text {nd }}$ edition). Basingstoke/New York: Palgrave MacMillan.

CHARTERIS-BLACK, J. (2016). Fire Metaphors. Discourses of Awe and Authority. London/New York: Bloomsbury.

CHILTON, P. (2004). Analysing Political Discourse. Theory and Practice. London/New York: Routledge.

CRESPO-FERNÁNDEZ, E. (2013). “Words as Weapons for Mass Persuasion: Dysphemism in Churchill's Wartime Speeches”. Text \& Talk 33 (3): 311-330.

CRESPO-FERNÁNDEZ, E. (2014). "Euphemism and Political Discourse in the British Regional Press”. Brno Studies in English 40 (1): 5-26.

CRESPO-FERNÁNDEZ, E. (2015). Sex in Language. Euphemistic and Dysphemistic Metaphors in Internet Forums. London/New York: Bloomsbury.

CRESPO-FERNÁNDEZ, E. and LÓPEZ CAMPILLO, R. M. (2011). "Persuasive Rhetoric in George Ridpath’s Political Writings”. ES Revista de Filología Inglesa 32: 43-67.

DUNTON, J. (1818). The Life and Errors of John Dunton, Citizen of London with the Lives and Characteristics of More than a Thousand Contemporary Divines, and Other Persons of Literary Eminence. Vol. II. London: J. Nichols, son, and Bentley.

GIBBS, R. W. (2011). “Evaluating Conceptual Metaphor Theory”. Discourse Processes 48 (8): 529-562.

GOATLY, A. (2006). "Humans, Animals and Metaphors”. Society and Animals 14 (1): 15-37.

GOFFMAN, E. (1967). Interaction Ritual: Essays on Face-to-Face Behaviour. New York: Double Day.

HATTENDORF, J. B. (1987). England in the War of the Spanish Succession. A Study of the English View and Conduct of Grand Strategy, 1702-1712. New York: Garland Publishing.

HOLMES, G. (1987). British Politics in the Age of Anne. London: The Hambledon Press.

KÖVECSES, Z. (2006). "Metaphor and Ideology in Slang: The Case of wOMAN and MAN". Revue d'Études Françaises 11: 151-166.

KÖVECSES, Z. (2010). "Metaphor and Culture”. Acta Universitatis Sapientiae, Philologica 2 (2): 197-220.

KÖVECSES, Z. and RADDEN, G. (1998). "Metonymy: Developing a Cognitive Linguistic View”. Cognitive Linguistics 9: 37-77.

KRÖLL, H. (1984). O eufemismo e o disfemismo no portugués moderno. Lisboa: Instituto de Cultura e Língua Portuguesa. 
LAKOFF, G. (1993). “The Contemporary Theory of Metaphor” in Metaphor and Thought. (Ed. A. Ortony). Cambridge: Cambridge University Press.

LAKOFF, G. and JOHNSON, M. (1980). Metaphors We Live By. Chicago: The University of Chicago Press.

LAKOFF, G. and TURNER, M. (1989). More than a Cool Reason. A Field Guide to Poetic Metaphor. Chicago: The University of Chicago Press.

LEE, W. (1869). The Life of Daniel Defoe. London: John Camden Rotter.

LÓPEZ CAMPILLO, R. M. (2009). "La Guerra de Sucesión Española: Opinión pública y propaganda política en Gran Bretaña durante el reinado de Ana Estuardo”. ENSAYOS, Revista de la Facultad de Educación de Albacete 24: 185-197.

LÓPEZ CAMPILLO, R. M. (2010). Daniel Defoe y la Guerra de Sucesión Española. Michigan: ProQuest.

LOSA SERRANO, P. and LÓPEZ CAMPILLO, R. M. (2007). "La Guerra de Sucesión Española: Swift, Defoe y la campaña para la paz”. Revista Estudis 33: $175-192$.

LUTZ, W. (1987). “Doublespeak at Large”. English Today 12: 20-24.

MARTIN, J. R. (2000). "Beyond Exchange: Appraisal Systems in English” in Evaluation in Text. (Eds. S. Hunston and G. Thompson). Oxford: Oxford University Press.

MARTIN, J. R. and WHITE, P. R. R. (2005). The Language of Evaluation. Appraisal in English. Hampshire/New York: Palgrave Macmillan.

MCGLONE, M. and BATCHELOR, J. A. (2003). “Looking Out for Number One: Euphemism and Face”. Journal of Communication 53: 251-264.

MCLEOD, W. R. and MCLEOD, V. B. (1979). Anglo-Scottish Tract, 1701-1714. A Descriptive Checklist Compiled by W. R. and V. B. McLeod. Lawrence: University of Kansas Publications.

MÜLLENBROCK, H. J. (1997). The Culture of Contention. A Rhetorical Analysis of the Public Controversy about the Ending of the War of the Spanish Succession, 1710-1713. Munich: Fink.

RIDPATH, G. (1709-1710). The Observator. Eighth volume. London: B. Bragge.

RIDPATH, G. (1710). The Observator. Ninth volume. B. Bragge, R. Janemay, S. Popping.

RIDPATH, G. (1711a). The Flying Post: or, the Post-master, 3032-3146. London: William Hurt.

RIDPATH, G. (1711b). The Observator. Tenth volume. London: S. Popping. RIDPATH, G. (1711-1712). The Observator. Eleventh volume. London: S. Popping, William Hurt. 
RIDPATH, G. (1712). The Flying Post: or, the Post-master, 3186-3316. London: William Hurt.

RIDPATH, G. (1713-1714). The Flying Post: or, the Post-master, 3319-3434. London: William Hurt.

RODRÍGUEZ GONZÁLEZ, F. (1991). Prensa y lenguaje político. Alicante: Instituto de Cultura Juan Gil-Albert.

RUIZ DE MENDOZA IBÁÑEZ, F. J. (2000). "The Role of Mappings and Domains in Understanding Metonymy" in Metaphor and Metonymy at the Crossroads. (Ed. A. Barcelona). Berlin/New York: Mouton de Gruyter.

RUIZ DE MENDOZA IBÁÑEZ, F. J. and GALERA-MASEGOSA, A. (2011). "Going beyond Metaphtonymy: Metaphoric and Metonymic Complexes in Phrasal Verb Interpretation”. Language Value 3 (1): 1-29.

RUIZ DE MENDOZA IBÁÑEZ, F. J. and PÉREZ HERNÁNEZ, L. (2011). “The Contemporary Theory of Metaphor: Myths, Developments and Challenges”. Metaphor and Symbol 26: 161-185.

SÁNCHEZ RUIZ, R. (2015). “George Ridpath's Use of Evaluative Adjectives as Manipulative and Persuasive Strategies during the War of the Spanish Succession (1710-1713)”. Journal of English Studies 13: 109-134.

SÁNCHEZ RUIZ, R. and LÓPEZ CIRUGEDA, I. (2015). "Persuasion and Manipulation through Conceptual Metaphors in George Ridpath's Political Writings (1707-1709)”. US-China Foreign Language 13 (6): 397-411.

SPECK, W. A. (1970). Tory and Whig. The Struggle in the Constituencies 17011715. London: MacMillan.

SWIFT, J. (1711). The Examiner 42.

TABOADA, M. and GRIEVE, J. (2004). "Analyzing Appraisal Automatically”. Proceedings of AAAI Spring Symposium on Attitude and Affect in Text: 158-161. TREVELYAN, G. M. (1965). England under Queen Anne. Volumes I-III. London: Longmans, Green and Co.

VAN DIJK, T. A. (1997). "What is Political Discourse Analysis?” in Political Linguistics (Comps. J. Blommaert and C. Bulcaen). Amsterdam/Philadelphia: John Benjamins.

VAN DIJK, T. A. (1999). Ideología: Una aproximación multidisciplinaria. Barcelona: Gedisa.

WILSON, W. (1830). Memoirs of the Life and Times of Daniel De Foe: Containing a Review of his Writings and his Opinions upon a Variety of Important Matters, Civil and Ecclesiastical. London: Hurst, Chance and Co. 